\title{
MODELOWANIE HAŁDY KRUSZYWA NATURALNEGO Z WYKORZYSTANIEM TECHNOLOGII UAV WRAZ Z ANALIZA DOKŁADNOŚCI
}

\author{
MACIEJ SMACZYŃSKI \\ Zakład Kartografii i Geomatyki, Wydział Nauk Geograficznych i Geologicznych, \\ Uniwersytet im. Adama Mickiewicza w Poznaniu, ul. B. Krygowskiego 10, 61-680 Poznań \\ ORCID: 0000-0002-8569-6013
}

\begin{abstract}
The purpose of this article is to determine the potential of imaging obtained using an unmanned aerial platform (UAV) to create a digital model of terrain for aggregate heaps (DTMs). In addition, the intermediate goal is to carry out an independent accuracy check of the calculated 3D model, which in the study will be referred to an independent measurement using GNSS technology. The research object was a heap of natural aggregate with irregular shape and height differences up to 11 meters. Three point clouds with different detail parameters were generated from the acquired images. For further analysis, a point cloud with the best ratio of terrain reflection accuracy to the calculated RMSE value was selected. Independent control of 3D model accuracy was based on seven heap control points measured in the field and the same points generated on the 3D model. The deviations of several centimeters between field control points and points from the model may indicate the great potential of UAV technology and the possibility of its use in various engineering tasks.
\end{abstract}

Keywords: UAV, GNSS, surface modeling, geomatics

\section{WPROWADZENIE}

Ukształtowanie terenu jako skutek działania człowieka podlega badaniom morfometrycznym w kierunku gospodarowania cechami fizycznymi tych nowych form antropogenicznych. Możliwość odtworzenia jak najbardziej rzeczywistego modelu terenu w środowisku cyfrowym, a następnie jego analiza i wizualizacja mogą w sposób znaczący pomóc w określeniu czynników wpływających na przestrzeń (Horbiński 2016; Horbiński, Medyńska-Gulij 2017). Stąd niezwykle ważne jest pozyskanie dokładnego numerycznego modelu terenu (NMT), który może stanowić podstawowy zestaw danych koniecznych do analiz w systemach informacji geograficznej. Rozwiązaniem tego problemu może być opracowanie NMT na podstawie danych otrzymanych za pomocą bezzałogowej platformy powietrznej (Unmanned Aerial Vehicles, UAV). Główną zaletą pozyskania danych z wykorzystaniem zdalnych technik pomiarowych jest możliwość uzyskania ciągłych danych przestrzennych w dokładnościach centymetrowych, a ponadto możliwość ich integracji z danymi uzyskanymi konwencjonalnymi naziemnymi technikami pomiarowymi (Tofani i in. 2013). Przez 
długi czas bezzałogowe statki powietrzne odgrywały znaczącą rolę w zadaniach militarnych (Watts i in. 2012). Były wykorzystywane na przykład w działaniach wywiadowczych, nadzorze środowiskowym i morskim czy podczas operacji usuwania min (Eisenbeiss 2004). To właśnie połączenie z sektorem wojskowym wpłynęło na znaczący rozwój bezzałogowych platform powietrznych i ich wszechstronne zastosowanie w latach 1960-1980 (Ahmad 2011). Obecnie bezzałogowe statki powietrzne wykorzystywane są nie tylko do celów wojskowych. Ich wykorzystanie w sektorze cywilnym wzrasta z roku na rok. W $2007 \mathrm{r}$. Komisja Europejska opublikowała raport na temat rozwoju technologii bezzałogowych statków powietrznych, w którym sektor cywilny i handlowy zostały podzielone na sześć następujących segmentów zastosowań: rząd; walka z ogniem; energia; rolnictwo, leśnictwo i rybołówstwo; obserwacja Ziemi i teledetekcja; komunikacja i transmisja danych (Komisja Europejska, 2007). Ponadto prowadzone badania wykazują duży potencjał technologii UAV w szybkim mapowaniu w sytuacjach kryzysowych (powodzie, pożary, konflikty itp.), co może bezpośrednio ułatwić procesy decyzyjne (Stępień i in. 2018). Możliwość wykorzystania bezzałogowców do prowadzenia obserwacji obszarów kopalni odkrywkowych, a w szczególności do określania zachodzących tam zmian oraz obliczeń kubaturowych na podstawie chmury punktów zostały opisane między innymi przez Esposito i in. (2017) na przykładzie Sa Pigada Bianca na Sardynii. Rozwój technologiczny produkcji bezzałogowców, a w szczególności miniaturyzacja oraz zmniejszenie kosztów wytwarzania podzespołów wykorzystywanych do ich tworzenia sprawił, że coraz częściej służą one jako urządzenia pomiarowe w badaniach geofizycznych. Obecnie ich wszechstronne zastosowanie w geofizyce, geodezji, planowaniu przestrzennym, hydrologii jest przedmiotem wielu badań (Goraj i in. 2019; Torres i in. 2016; Remondino i in. 2012; Li i in. 2016; Kršák i in. 2016; Siebert, Teizer 2014; Lin 2008).

\section{CEL BADAŃ}

Głównym celem prowadzonych badań jest określenie możliwości wykorzystania bezzałogowej platformy powietrznej do modelowania rzeźby terenu na przykładzie hałdy kruszywa naturalnego. Pośrednim celem niniejszego badania jest ocena wygenerowanego modelu $3 \mathrm{D}$. W tym celu autor badania porównat dokładności opracowanego modelu 3D na podstawie zachowania rzeczywistych wymiarów liniowych i kątowych między punktami kontrolnymi. Dokonano tego przez zestawienie współrzędnych punktów kontrolnych modelu 3D z wynikami geodezyjnych pomiarów terenowych GNSS RTK tychże punktów. Ponadto $\mathrm{w}$ badaniu przedstawiono charakterystykę otrzymanych modeli 3D, wygenerowanych z różnym stopniem dokładności i szczegółowości w oprogramowaniu fotogrametrycznym. Podczas badań wykorzystano geomatyczną metodę 
badawczą (Medyńska-Gulij 2015), w której w sposób komplementarny łączy się klasyczne pomiary terenowe $\mathrm{z}$ działaniami np. obliczeniowymi, wykonywanymi w dedykowanym oprogramowaniu komputerowym (Kozieł 1997).

\section{OBSZAR BADAŃ}

Badanie przeprowadzono na terenie kopalni odkrywkowej kruszywa naturalnego „Gołun”, zlokalizowanej w zachodniej części Polski, w województwie Wielkopolskim, na obszarze powiatu poznańskiego (ryc. 1). Główne punkty graniczne żwirowni, na której prowadzono badania, zestawiono w tabeli 1. Wybrany obszar charakteryzuje się dużą liczbą odkrywkowych kopalń, które znacząco wpływają na zmiany ukształtowania rzeźby terenu. Do badań została wybrana hałda kruszywa naturalnego zajmująca powierzchnię $6500 \mathrm{~m}^{2}$, charakteryzująca się urozmaiconym kształtem, z wyraźnie widocznymi zagłębieniami i wypukłościami powierzchni. Deniwelacja wybranej hałdy wynosiła ponad $11 \mathrm{~m}$.

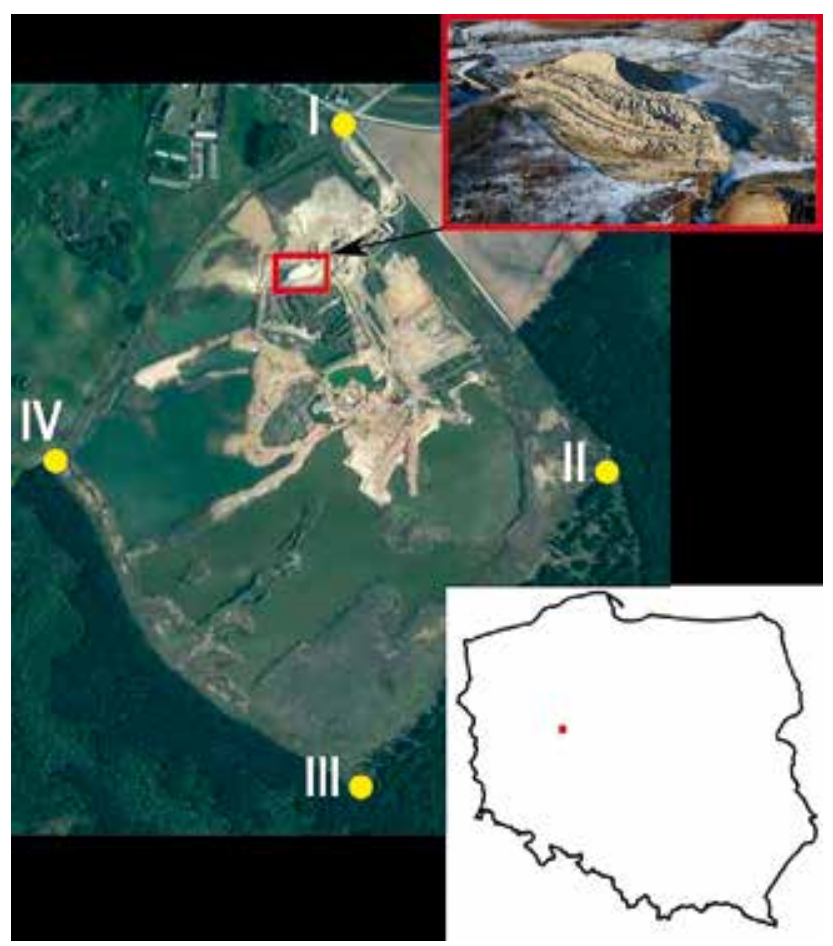

Ryc. 1. Lokalizacja obszaru badań

Fig. 1. Location of the study area Źródło: oprac. własne na podstawie: <https://geoportal.gov.pl/> 
Tabela 1. Wykaz punktów granicznych obszaru badań

Table 1. List of boundary points of the research area

\begin{tabular}{ccc}
\hline Punkt & X (PL-2000 strefa 6) & Y (PL-2000 strefa 6) \\
\hline I & 5814228,00 & 6455180,00 \\
II & 5813585,00 & 6455704,00 \\
III & 5813560,00 & 6454620,00 \\
IV & 5812934,00 & 6455241,00 \\
\hline
\end{tabular}

\section{ZAPLANOWANIE NALOTU FOTOGRAMETRYCZNEGO}

Podczas kameralnego projektowania nalotu istotną rolę odgrywają mapowe podkłady kartometryczne, przydatne w celu sytuacyjnej orientacji analizowanego obszaru (Kędzierski i in. 2014). Ponadto, jak zaznacza Ostrowski i in. (2016), do zdefiniowania strefy nalotu oraz stacji kontroli naziemnej praktycznym rozwiązaniem okazuje się wykorzystanie satelitarnych obrazów badanego obszaru. W przeprowadzonym badaniu użyto zarówno kartometryczny podkład mapowy, jak i ortofotomapy pobrane z krajowego geoportalu (www.geoportal.gov. pl), wykorzystane do określenia potencjalnego miejsca założenia osnowy fotogrametrycznej. Na podstawie pozyskanych zobrazowań z nalotu bezzałogową platformą powietrzną możliwe jest uzyskanie chmur punktów o bardzo dużej rozdzielczości wraz z numerycznymi modelami terenu (NMT), ortofotomapami i dokładnymi modelami 3D powierzchni terenu (Colomina, Molina 2014; Clapuyt $\mathrm{i}$ in. 2017). Proces tworzenia wymienionych opracowań fotogrametrycznych zwykle przeprowadza się z wykorzystaniem oprogramowania z algorytmem Structure-from-Motion (SfM). Przy jego użyciu możliwe jest obliczenie modelu 3D na podstawie szeregu nachodzących na siebie zobrazowań rejestrujących modelowany obiekt z różnych perspektyw (Westoby i in. 2012). Planując nalot fotogrametryczny z wykorzystaniem bezzałogowej platformy powietrznej, uznano, że w celu uzyskania modelu o kilkucentymetrowej dokładności rzeźby terenu na obszarze badań założona zostanie osnowa fotogrametryczna. Jest ona niezbędna do przeprowadzenia procesu aerotriangulacji, w tym do otrzymania dokładnych wartości elementów orientacji zewnętrznej każdego ze zdjęć (Uysal i in. 2015). Należy podkreślić, że pośrednim celem było przeprowadzenie niezależnej kontroli dokładności sytuacyjno-wysokościowej uzyskanego modelu fotogrametrycznego rzeźby terenu. Aby było to możliwe, na obszarze badań dodatkowo założono punkty kontrolne, stanowiące niezależną sieć kontrolną (Gonçalves, Henriques 2015). Wybrane punkty kontrolne, wykorzystane do przeprowadzenia oceny wykonanego procesu aerotriangulacji, nie będą uwzględniane $\mathrm{w}$ procesie aerotriangulacji. Założono, że proces kontroli otrzymanego w niniejszym badaniu modelu fotogrametrycznego polegać będzie na 
porównaniu współrzędnych punktów kontrolnych pomierzonych metodą GNSS RTK oraz współrzędnych tych samych punktów uzyskanych z numerycznego modelu terenu (Smaczyński, Medyńska-Gulij 2017).

\section{ZAŁOŻENIE I POMIAR OSNOWY FOTOGRAMETRYCZNEJ}

Podczas prac pomiarowych związanych z wykorzystaniem bezzałogowych statków powietrznych ważne jest nie tylko odpowiednie zaplanowanie samego nalotu, ale również sieci punktów osnowy fotogrametrycznej (Nex, Remondino 2014). W przypadku gdy wykorzystywana w procesie nalotu platforma bezzałogowa nie ma inercyjnego systemu nawigacji (IMU) lub gdy odbierany sygnał satelitarny jest zakłócony, założenie osnowy fotogrametrycznej jest konieczne już podczas kameralnego projektowania nalotu (Anai i in. 2012; Barazzetti i in. 2010; Eugster, Nebiker 2008; Wang i in. 2008). Siebert i Teizer (2014) podają, że założenie osnowy fotogrametrycznej jest niezbędne w szczególności, gdy celem jest wygenerowanie kartometrycznego modelu rzeźby terenu, a sam pomiar punktów powinien zostać wykonany z wykorzystaniem technik geodezyjnych takich jak obserwacje satelitarne czy tachimetria. Uważa się, że obecnie najlepszym i wystarczającym sposobem pomiaru jest przeprowadzenie obserwacji satelitarnych w czasie rzeczywistym (Real Time Kinematic, RTK), co przyczynia się do poprawy obliczeń elementów orientacji wewnętrznej kamery w procesie aerotriangulacji (de Kock, Gallacher 2016).

$\mathrm{W}$ prowadzonym badaniu do pomiaru punktów osnowy fotogrametrycznej wykorzystano kinematyczną metodę pozycjonowania satelitarnego (GNSS RTK), przy użyciu odbiornika Trimble R4 model 3. Współrzędne pozyskane z wykorzystaniem technologii satelitarnego pozycjonowania zdefiniowano $\mathrm{w}$ obowiązującym w Polsce podczas wykonywania prac geodezyjnych układzie współrzędnych płaskich prostokątnych PL-2000 (strefa VI) (Dz.U. 2012, poz. 1247; Bosy 2014). W związku z tym, że zobrazowania pozyskiwane z wykorzystaniem technologii UAV często charakteryzują się ukośną orientacją, zaleca się, aby na obszarze podlegającym pomiarowi założyć dużą liczbę punktów stanowiących osnowę fotogrametryczną (Ruzgienè i in. 2015). Biorąc pod uwagę wielkość obrazowanego obiektu, w niniejszym badaniu założono cztery sygnalizowane punkty osnowy fotogrametrycznej (ryc. 2). Zostały one zlokalizowane z każdej strony obserwowanej hałdy kruszywa naturalnego. Punkty osnowy fotogrametrycznej zestabilizowano $\mathrm{w}$ terenie $\mathrm{z}$ wykorzystaniem drewnianych palików. Oznaczone je pomarańczową farbą fluorescencyjną w celu jednoznacznej identyfikacji na zobrazowaniu (Siebert, Teizer 2014). Aby przeprowadzić sytuacyjno-wysokościową kontrolę uzyskanego modelu fotogrametrycznego, na obszarze badań założono siedem niezależnych punktów kontrolnych oznaczonych numerami od 1 do 7 (ryc. 2 - Check Points). Pięć niezależnych punktów kontrolnych zlokalizowano 
u podstawy hałdy kruszywa, a dwa pozostałe na jej szczycie. Należy podkreślić, że zdefiniowanych w badaniu punktów kontrolnych nie wykorzystano w procesie aerotriangulacji pozyskanych zobrazowań (Toutin, Chénier 2004). Lokalizacja wszystkich założonych punktów osnowy fotogrametrycznej oraz niezależnych punktów kontrolnych została przedstawiona na rycinie 2 .

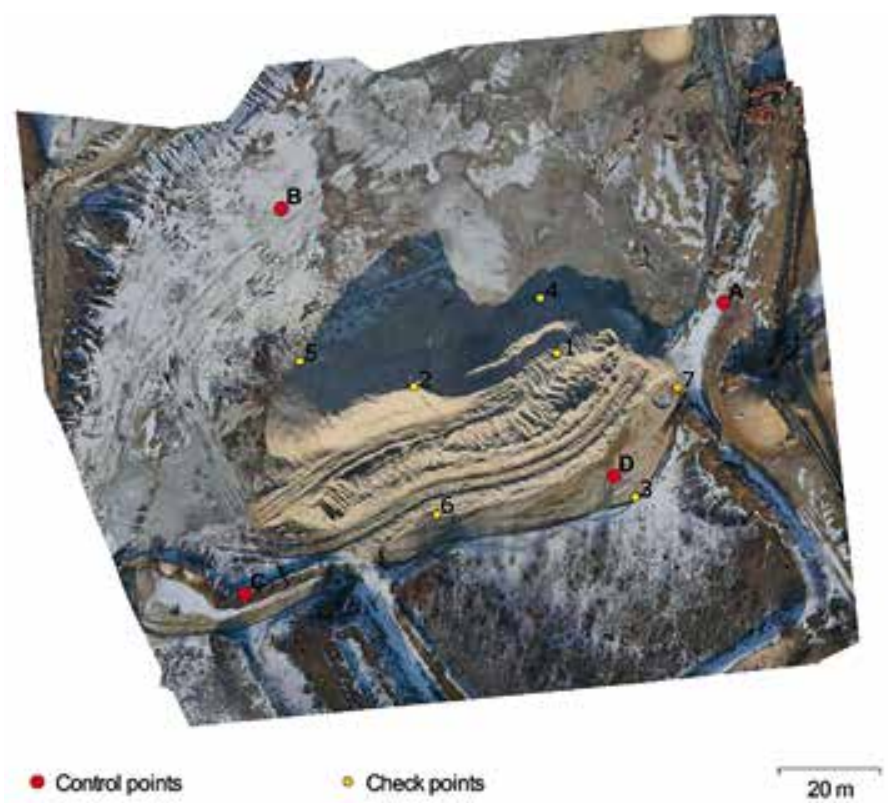

Ryc. 2. Lokalizacja punktów osnowy fotogrametrycznej i niezależnych punktów kontrolnych na obszarze badań

Fig. 2. Location of Ground Control Points and Independent Control Points on the research area

\section{POZYSKANIE DANYCH OBRAZOWYCH - NALOT}

W badaniu do pozyskania zobrazowań z niskiego pułapu lotniczego wykorzystano bezzałogową platformę powietrzną konstrukcji wielowirnikowej zbudowanej na ramie Tarot X6. Do uzyskania zobrazowań użyto bezzałogowca wyposażonego w aparat fotograficzny Panasonic DMC-GH4 o matrycy 16,1 Mpx z obiektywem normalnokątnym DJI Zenmuse X5 (ryc. 3).

Mając na uwadze wielkość badanego obiektu, określono, że nalot będzie prowadzony z wysokości $100 \mathrm{~m}$ AGL (Above Ground Level), co pozwoli uzyskać rozdzielczość terenową na poziomie $2,5 \mathrm{~cm} / \mathrm{px}$, a obserwowany obiekt w celu dalszej analizy sfotografowany zostanie ze wszystkich stron. Takie podejście umożliwi zarejestrowanie całej hałdy kruszywa naturalnego przez wykorzystanie algorytmu SfM (Westoby i in. 2012). W trakcie prowadzenia nalotu 
panowały dogodne warunki atmosferyczne. Prędkość wiatru wynosiła około $3 \mathrm{~m} / \mathrm{s}$, nie występowały opady atmosferyczne. W wyniku nalotu trwającego 30 min pozyskano łącznie 103 zobrazowania, na których zarejestrowano badaną formę terenu.

W celu zrealizowania dalszych prac badawczych przeprowadzono manualną selekcję zbioru zobrazowań. Miała ona na celu minimalizację liczby zobrazowań z zachowaniem jak najlepszej prezentacji rejestrowanego obiektu. W wyniku wyboru do dalszych badań przyjęto 10 zobrazowań, na których badana hałda została zarejestrowana na dwóch zobrazowaniach z każdej ze stron oraz dodatkowo na dwóch zobrazowaniach $\mathrm{w}$ projekcji ortogonalnej, obrazujących szczyt hałdy kruszywa naturalnego (ryc. 4).

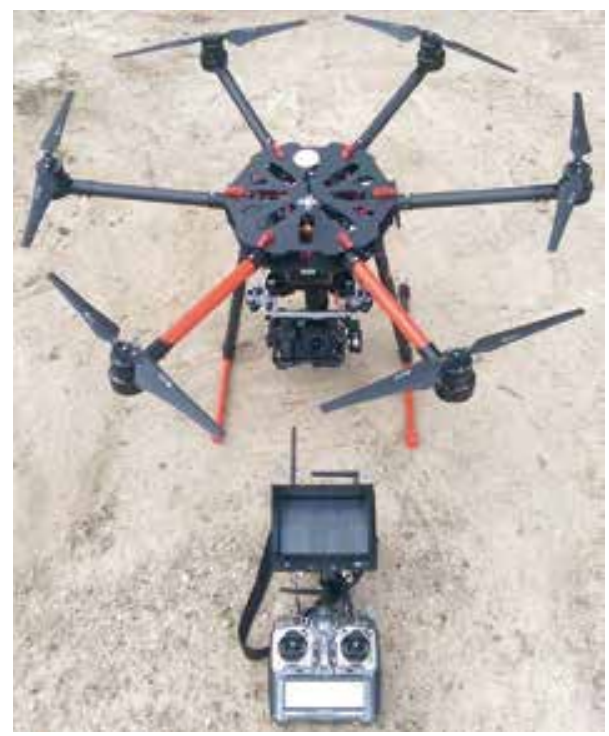

Ryc. 3. Widok wykorzystanej w badaniu bezzałogowej platformy powietrznej

Fig. 3. View of the unmanned aerial platform used in the research

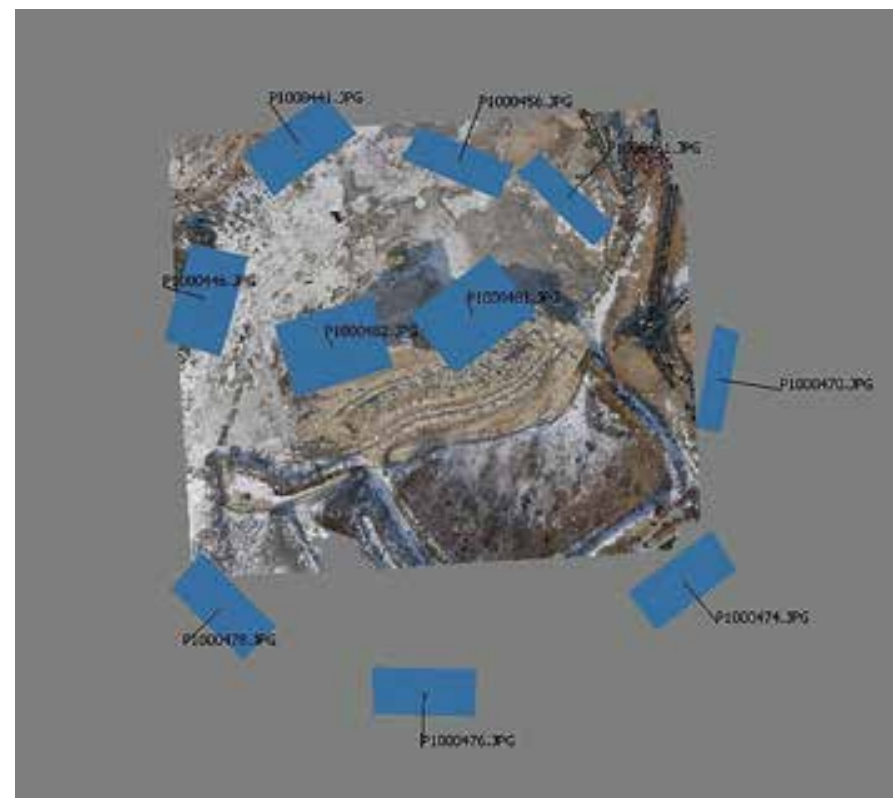

Ryc. 4. Lokalizacja zobrazowań wybranych do dalszego badania Fig. 4. Location of images selected for further study 


\section{AEROTRIANGULACJA}

Kolejną czynnością było zdefiniowanie wybranych zobrazowań w wybranym układzie współrzędnych. Pierwszym krokiem prowadzącym do aerotriangulacji pozyskanych zobrazowań jest odtworzenie ich wzajemnej orientacji wewnętrznej (Siebert, Teizer 2014). W badaniu zobrazowania zostały wpasowane w tożsamy układ współrzędnych, w którym zdefiniowano punkty osnowy fotogrametrycznej. Odtworzenie wzajemnej orientacji wewnętrznej zobrazowań jest możliwe dzięki wykorzystaniu plików EXIF zawierających metadane opisujące zobrazowanie, co pozwala na ustalenie ich przybliżonej lokalizacji w przestrzeni. Konieczność wygenerowania kartometrycznego modelu rzeźby terenu determinuje ponowne odtworzenie wzajemnej orientacji zobrazowań, lecz już na podstawie założonych punktów osnowy fotogrametrycznej, które wcześniej pomierzono metodą satelitarnego pozycjonowania GNSS. Do wykonania tego zadania wybrano oprogramowanie Agisoft PhotoScan Professional. Wspomniane oprogramowanie znajduje szczególne zastosowanie przy opracowywaniu zobrazowań pozyskanych $\mathrm{z}$ bezzałogowych statków powietrznych oraz umożliwia wygenerowanie numerycznego modelu terenu czy ortofotomapy w dowolnie zdefiniowanym przez użytkownika układzie współrzędnych (Uysal i in. 2015). Należy dodać, że przed przystąpieniem do procesu obliczeniowego we wspomnianym oprogramowaniu przeprowadzono kalibrację wykorzystanego podczas nalotu aparatu fotograficznego w programie Agisoft Lens. Zaimplementowany w nim model dystorsji Browna pozwala na określenie i uwzględnienie $\mathrm{w}$ dalszych pracach obliczeniowych występującej w obiektywie dystorsji radialnej i tangencjalnej (Gonçalves, Henriques 2015).

W trakcie przeprowadzonego procesu aerotriangulacji, opartego na założonej osnowie fotogrametrycznej, obliczona została wartość RMSE (Root Mean Square Error), opisująca odchyłki między wejściowymi punktami nawiązania a punktami obliczonymi z wygenerowanego modelu fotogrametrycznego (Kršák i in. 2016). Jak podają Smaczyński i Medyńska-Gulij (2017), obliczenie wartości RMSE jest możliwe z wykorzystaniem następującej formuły:

$$
\mathrm{RMSE}= \pm \sqrt{\sum_{i=1}^{n} \frac{\left(X_{i, e s t}-X_{i, \text { in }}\right)^{2}+\left(Y_{i, e s t}-Y_{i, i n}\right)^{2}+\left(Z_{i, e s t}-Z_{i, \text { in }}\right)^{2}}{n}}
$$

gdzie:

$\mathrm{X} / \mathrm{Y} / \mathrm{Z}_{\mathrm{i}, \text { in }}$ - wskazana wartość współrzędnej,

$\mathrm{X} / \mathrm{Y} / \mathrm{Z}_{\mathrm{i}, \text { sst }}$ - wyestymowana wartość współrzędnej. 
Z otrzymanych wyników obliczeń wywnioskowano, że punktem osnowy fotogrametrycznej obarczonym najmniejszym całkowitym błędem wpasowania jest punkt $\mathrm{D}$, natomiast największym punkt $\mathrm{B}$ (tab. 2). Ponadto w badaniu przeprowadzona zostanie ocena procesu aerotriangulacji na podstawie niezależnych punktów osnowy fotogrametrycznej (Smaczyński, Medyńska-Gulij 2017). Wartość błędu obliczona na podstawie wszystkich wykorzystanych punktów osnowy fotogrametrycznej w procesie aerotriangulacji wynosiła $1,1 \mathrm{~cm}$, co odpowiada 0,11 px (tab. 2) (Dz.U. $2011 \mathrm{Nr} 263$, poz. 1571).

Tabela 2. Zestawienie obliczonych błędów aerotriangulacji

Table 2. Summary of calculated aerotriangulation errors

\begin{tabular}{lcccc}
\hline Punkt osnowy & Oś X [cm] & Oś Y [cm] & Oś Z [cm] & Całkowity błąd [cm] \\
\hline B & 0,20 & 1,36 & $-0,22$ & 1,39 \\
D & $-0,04$ & $-0,10$ & $-0,70$ & 0,71 \\
A & $-0,82$ & $-0,38$ & 0,56 & 1,07 \\
C & 0,67 & $-0,88$ & 0,36 & 1,16 \\
Całkowity błąd & 0,54 & 0,83 & 0,50 & 1,11 \\
\hline
\end{tabular}

Kolejnym krokiem do utworzenia modelu rzeźby terenu było wygenerowanie na podstawie wybranych zobrazowań serii trójwymiarowych chmur punktów analizowanego obiektu. Założono, że utworzone zostaną trzy chmury punktów obrazujące rzeźbę terenu (tab. 3). Określono, że będą one różnić się parametrami obliczeniowymi definiowanymi bezpośrednio w oprogramowaniu Agisoft PhotoScan Professional. Ustalono, że pierwsza chmura punktów zostanie opracowana na podstawie zobrazowań o oryginalnych rozmiarach, tj. 4608 x 2592 pikseli (model 1). Kolejna chmura punktów (model 2) będzie obliczona na podstawie zobrazowań, których rozmiar został zmniejszony o współczynnik równy cztery, co oznacza zmniejszenie jego wielkości dwukrotnie na każdej krawędzi. Ponadto obliczono najmniejszą chmurę punktów (model 3), której utworzenie oparto na zobrazowaniu zmniejszonym o wartość współczynnika 16, czyli czterokrotnie na każdym z boków.

Tabela 3. Zestawienie parametrów wygenerowanych modeli 3D

Table 3. List of parameters of generated 3D models

\begin{tabular}{lccc}
\hline \multicolumn{1}{c}{ Zmienna } & Model 1 & Model 2 & Model 3 \\
\hline Liczba punktów & 6793338 & 1642114 & 374896 \\
Gęstość [liczba punktów/m²] & 1420 & 90,1 & 5,1 \\
Wartość RMSE [cm] & 1,73 & 1,11 & 1,58 \\
Liczba płaszczyzn & 1358656 & 109468 & 19999 \\
Liczba wierzchołków & 681497 & 55467 & 10241 \\
\hline
\end{tabular}




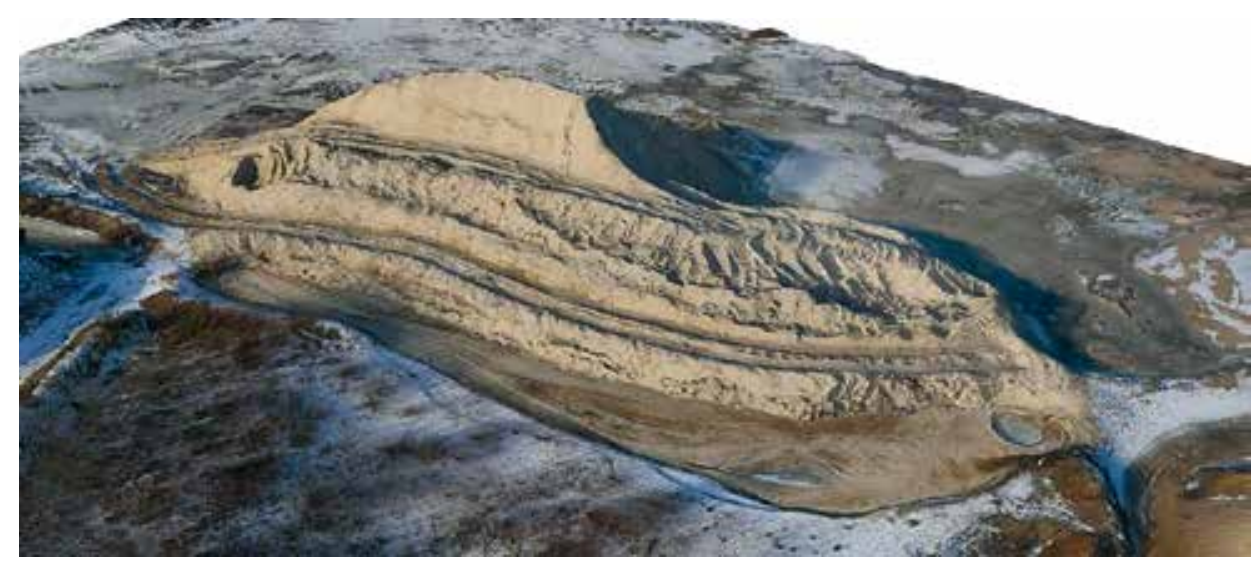

Ryc. 5. Wygenerowany model rzeźby terenu wraz z nałożoną teksturą

Fig. 5. Generated terrain model with applied texture

$\mathrm{Z}$ analizy parametrów utworzonych modeli 3D hałdy kruszywa naturalnego, obliczonych na podstawie chmury punktów, wynika, że największe różnice występują w zmiennych opisujących parametry chmury punktów. Jednakże stwierdzono, że różnice między obliczonymi wartościami RMSE modeli rzeźby terenu w ujęciu geodezyjnym wynoszą około $6 \mathrm{~mm}$. Na tej podstawie do dalszej oceny sytuacyjno-wysokościowej wybrano model 2 jako dokładne odzwierciedlenie rzeczywistego ukształtowania terenu, a ponadto charakteryzował się najmniejszą wartością RMSE. Trójwymiarowy model rzeźby terenu wraz z nałożoną teksturą przedstawiono na rycinie 5 .

\section{OCENA SYTUACYJNO-WYSOKOŚCIOWA MODELU 3D RZEŹBY TERENU}

Uzyskane w wyniku przeprowadzonego procesu aerotriangulacji wartości RMSE stanowią jedynie błąd średni wpasowania modelu fotogrametrycznego wyznaczonego na podstawie przyjętych punktów osnowy fotogrametrycznej (Uysal i in. 2015). Podobnie jak w przypadku klasycznych pomiarów geodezyjnych uzyskane wyniki pomiarów z wykorzystaniem bezzałogowego statku powietrznego powinny być poddane niezależnej kontroli (Kujawski, Stępień 2017; Smaczyński, Medyńska-Gulij 2017). Toutin i Chénier (2004) podają, że czynność tę należy oprzeć na wcześniej założonych i pomierzonych niezależnych punktach kontrolnych, które nie zostały bezpośrednio wykorzystane w procesie aerotriangulacji. Autor badania przyjął, że współrzędne punktów kontrolnych 1-7, które zostały uzyskane w wyniku pomiaru metodą pozycjonowania satelitarnego, będą stanowiły punkty referencyjne do oceny dokładności. Punkty te 
oznaczono przyrostkiem „gnss”. Współrzędne uzyskane na podstawie modelu fotogrametrycznego oznaczono przyrostkiem ,uav". Analiza modelu rzeźby terenu obliczonego w badaniu polegała na korelacji obu zbiorów współrzędnych. W jej wyniku uzyskano różnice wartości względem półosi układu współrzędnych, tj. $\Delta \mathrm{X}, \Delta \mathrm{Y}, \Delta \mathrm{H}$ (tab. 4).

Tabela 4. Różnice wartość współrzędnych niezależnych punktów kontrolnych

Table 4. Differences in the coordinate value of independent control points

\begin{tabular}{rccc}
\hline Punkt & $\Delta \mathrm{X}[\mathrm{m}]$ & $\Delta \mathrm{Y}[\mathrm{m}]$ & $\Delta \mathrm{H}[\mathrm{m}]$ \\
\hline 1gnss - 1uav & 0,000 & 0,024 & 0,038 \\
2gnss - 2uav & $-0,015$ & $-0,003$ & $-0,011$ \\
3gnss - 3uav & $-0,018$ & $-0,002$ & $-0,015$ \\
4gnss - 4uav & $-0,016$ & $-0,001$ & $-0,105$ \\
5gnss - 5uav & 0,006 & $-0,004$ & $-0,035$ \\
6gnss - 6uav & $-0,006$ & $-0,012$ & $-0,012$ \\
7gnss - 7uav & $-0,012$ & 0,008 & 0,024 \\
\hline
\end{tabular}

Na podstawie zestawionych w tabeli 4 wyników stwierdza się, że punktem kontrolnym obarczonym najmniejszym błędem sytuacyjnym był punkt 5 , natomiast najmniej korzystnym wynikiem charakteryzował się punkt 1 . Biorąc pod uwagę składową wysokościową, najkorzystniejszym wynikiem odznacza się punkt $2(1,1 \mathrm{~cm})$, natomiast najgorszym punkt $4(10,5 \mathrm{~cm})$. Należy podkreślić, że odchyłka wysokościowa pozostałych punktów kontrolnych nie przekroczyła $4 \mathrm{~cm}$. Stąd wartość odchyłki wysokościowej zarejestrowanej w punkcie 4 może zostać potraktowana jako odstająca. W prowadzonym badaniu tak duży wpływ na wysokość punktu 4 mogło mieć jego usytuowanie. Punkt 4 znajdował się po zacienionej północnej stronie hałdy kruszywa naturalnego. Piksele znajdujące się w jego bezpośrednim sąsiedztwie były w dużym stopniu barwnie jednolite. W konsekwencji taka sytuacja mogła spowodować wystąpienie szumów obrazu, które bezpośrednio mogły przełożyć się na otrzymanie błędnych wyników. Należy zauważyć, że mimo wykorzystania w procesie aerotriangulacji punktów osnowy fotogrametrycznej zestabilizowanych na wysokości podstawy hałdy, punkty kontrolne 1 i 2, znajdujące się w dwóch niezależnych miejscach na szczycie hałdy kruszywa, obarczone zostały bardzo małymi błędami wpasowania. Pomimo jednej odstającej wartości wysokościowej na podstawie otrzymanych w niniejszym badaniu wyników można stwierdzić, że wygenerowany model rzeźby terenu charakteryzuje się wysoką dokładnością sytuacyjno-wysokościową. 


\section{WNIOSKI}

Na podstawie obliczonych odchyłków lokalizacji punktów kontrolnych pomierzonych z wykorzystaniem technologii satelitarnego pozycjonowania GNSS RTK oraz tych samych punktów uzyskanych na podstawie zobrazowań $\mathrm{z}$ niskiego pułapu lotniczego ustalono, że z zastosowaniem w badaniu geomatycznej metody badawczej oraz algorytmu SfM (Westoby i in. 2012) możliwe jest wygenerowanie szczegółowego modelu rzeźby terenu z dokładnością kilkucentymetrową (ryc. 5). Uściślając, jest to możliwe przede wszystkim dzięki prowadzeniu prac przy użyciu specjalistycznego oprogramowania komputerowego, za pomocą którego możliwe było przetworzenie danych obrazowych pozyskanych z wykorzystaniem bezzałogowej platformy powietrznej do postaci cyfrowej. W środowisku komputerowym możliwe było odniesienie uzyskanych modeli 3D do pomiarów geodezyjnych GNSS RTK. Przeprowadzenie niezależnej kontroli obliczonego modelu 3D rzeźby terenu na siedmiu punktach kontrolnych pozwala stwierdzić, że obliczona w oprogramowaniu Agisoft PhotoScan Professional wartość RMSE, wynosząca 1,11 cm (tab. 2 i 3), jest prawdopodobna na poziomie ufności $68 \%$. Na szczególną uwagę zasługuje kontrola sytuacyjno-wysokościowa w punktach 1 i 2 . Należy zaznaczyć, że wymienione punkty w przeciwieństwie do zlokalizowanych na wysokości podstawy badanej hałdy punktów osnowy fotogrametrycznej wykorzystanych w procesie aerotriangulacji znajdowały się na jej szczycie (ryc. 2). Mimo takiej ich lokalizacji obliczona odchyłka sytuacyjno-wysokościowa jest bardzo mała (tab. 4). Ponadto obliczona w niniejszym badaniu chmura punktów (model 2 - tab. 3) liczyła ponad 1,5 mln punktów, co zapewniło otrzymanie gęstości punktów na poziomie 90 punktów na każdy metr kwadratowy. W odniesieniu do klasycznych geodezyjnych technik pomiarowych uzyskanie analogicznego modelu rzeźby terenu byłoby bardzo trudne oraz przede wszystkim czasochłonne. Otrzymane wyniki badań powalają potwierdzić wysoki potencjał i przydatność technologii UAV $w$ pracach związanych z modelowaniem ukształtowania rzeźby terenu. Przeprowadzona analiza dokładności obliczonego modelu daje możliwość wykorzystania opracowanych modeli 3D w precyzyjnych wielkoskalowych pracach inżynierskich a także w konstrukcji w systemie wirtualnej rzeczywistości (Halik, Smaczyński 2018). Z przedstawionego w artykule przykładu wynika, że technologia UAV może być skutecznie wykorzystywana do ważnego z punktu widzenia kopalni odkrywkowych zadania, jakim jest geodezyjny monitoring deformacji, który może przyczynić się do poprawy bezpieczeństwa i poprawy zarządzania wydobyciem kruszywa (Karsznia i in. 2010). 


\section{LITERATURA}

Ahmad A., 2011: Digital mapping using low altitude UAV. Pertanika Journ. of Sc. and Technol., 19(S), 51-58.

Anai T., Sasaki T., Osaragi K., Yamada M., Otomo F., Otani H., 2012: Automatic Exterior Orientation Procedure for Low-Cost Uav Photogrammetry Using Video Image Tracking Technique and Gps Information. ISPRS - International Archives of the Photogrammetry. Remote Sensing and Spatial Information Sc., XXXIX-B7(September), 469-474, <http://doi.org/10.5194/ isprsarchives-XXXIX-B7-469-2012>.

Barazzetti L., Remondino F., Scaioni M., Brumana R., 2010: Fully automatic UAV image-based sensor orientation. Internat. Arch. of Photogrammetry Remote Sensing and Spatial Information Sciences Vol. XXXVIII Part 5 Commission V Symposium, 6. Retrieved from $<\mathrm{http}: / /$ www.isprs.org/proceedings/XXXVIII/part1/12/12_02_Paper_75.pdf >.

Bosy J., 2014: Global, regional and national geodetic reference frames for geodesy and geodynamics. Pure and Applied Geo-physics, 171(6), 783-808.

Clapuyt F., Vanacker V., Schlunegger F., van Oost K., 2017: Unravelling earth flow dynamics with 3-D time series derived from UAV-SfM models. Earth Surface Dynamics, 5, 791-806, <https:// doi.org/10.5194/esurf-5-791-2017>.

Colomina I., Molina P., 2014: Unmanned aerial systems for photogrammetry and remote sensing: a review. ISPRS J Photogramm Remote Sens, 92, 79-97.

Eisenbeiss H., 2004: A mini unmanned aerial vehicle (UAV): System overview and image acquisition. Proceedings of the Internat. Workshop on Processing and Visualization using High-Resolution Imagery, <https://doi.org/10.1017/ S0003598X00047980>.

Esposito G., Mastrorocco G., Salvini R., Oliveti M., Starita P., 2017: Application of UAV photogrammetry for the multitemporal estimation of surface extent and volumetric excavation in the Sa Pigada Bianca open-pit mine, Sardinia, Italy. Environmental Earth Sc., 76(3), 103, $<$ https://doi.org/10.1007/ s12665-017-6409-z>.

Eugster H., Nebiker S., 2008: Uav-Based Augmented Monitoring - Real-Time Georeferencing and Integration of Video Imagery With Virtual Globes. Arch., 37, 1229-1236.

European Commission, 2007: Study analysing the current activities in the field of UAV. ENTR/2007/065.

Gonçalves J.A., Henriques R., 2015: UAV photogrammetry for topographic monitoring of coastal areas. ISPRS Journ. of Photogrammetry and Remote Sensing, 104, 101-111. DOI: http://doi. org/10.1016/j.isprsjprs.2015.02.009.

Goraj M., Karsznia K., Sikorska D., Hejduk L., Chormański J., 2019: Multi-wavelength airborne laser scanning and multispectral UAV-borne imaging. Ability to distinguish selected hydromorphological indicators. Conference Paper. $18^{\text {th }}$ Internat. Multidisciplinary Sc. GeoConference SGEM2018, At Vienna.

Halik Ł., Smaczyński M., 2018: Geovisualisation of relief in a virtual reality system on the basis of low aerial images. Pure and Applied Geoph., 175, 9, 3209-3221.

Horbiński T., 2016: Dokumentacja kartograficzna zmian wydobycia kruszywa naturalnego w powiecie gnieźnieńskim w latach 2005-2015. Bad. Fizjograf. nad Pol. Zach. Ser. A - Geogr. Fiz., A67, 41-54. DOI: 10.14746/bfg.2016.7.4.

Horbiński T., Medyńska-Gulij B., 2017: Geovisualisation as a process of creating complementary visualisations: static two-dimensional, surface three-dimensional, and interactive. Geodesy \& Cartography, 66, 1, 2017, 45-58. DOI: 10.1515/geocart-2017-0009.

Karsznia K., Skalski Z., Czarnecki L., 2010: System ciagłego monitoringu deformacji odkrywkowych wyrobisk górniczych a bezpieczeństwo prowadzenia robót górniczych. Przegl. Górniczy, R. 2010, t. 66, nr 10, 167-171.

Kędzierski M., Fryśkowska A., Wierzbicki D., 2014: Opracowania fotogrametryczne z niskiego pułapu. Wojskowa Akad. Techn., Warszawa. 
de Kock M.E., Gallacher D., 2016: From drone data to decisions: Turning images into ecological answers. Conference: Innovation Arabia 9 (February).

Kozieł Z., 1997: Concerning the need for development of the geomatic research method. Geodezja i Kartografia, 663, 217-224.

Kršák B., Blistan P., Pauliková A., Puskarova P., Kovanič L., Palková J., Zelizňaková V., 2016: Use of low-cost UAV photogrammetry to analyse the accuracy of a digital elevation model in a case study. Measurement, 91, 276-287.

Kujawski A., Stępien G., 2017: A method of determining inland vessel position using a single stationary, non-metric camera. Sc. Journ. of the Maritime Univ. of Szczecin, 52(124), 103-111. DOI: $10.17402 / 251$.

Lin Z., 2008: UAV for mapping-low altitude photogrammetric survey. The Internat. Arch. of the Photogrammetry, Remote Sensing and Spatial Information Sc., 37(Part B1), 1183-1186, $<$ http://citeseerx.ist.psu.edu/viewdoc/download?>. DOI: 10.1.1.150.9698\&rep=rep1\&type$=$ pdf.

Medyńska-Gulij B., 2015: Kartografia. Zasady i zastosowania geowizualizacji. Wyd. Nauk. PWN, Warszawa, 228.

Nex F., Remondino F., 2014: UAV for 3D mapping applications: A review. Applied Geomatics, 6(1), 1-15, <http://doi.org/10.1007/s12518-013-0120-x>.

Ostrowski W., Hanus K., 2016: Budget UAV systems for the prospection of small- and mediumscale archaeological sites. ISPRS Arch. of Photogrammetry, Remote Sensing and Spatial Information Sc., 41(July), 971-977.

Remondino F., Barazzetti L., Nex F., Scaioni M., Sarazzi D., 2012: UAV Photogrammetry for mapping and $3 D$ modeling-current status and future perspectives. ISPRS - Internat. Arch. of the Photogrammetry, Remote Sensing and Spatial Information Sc., 38-1(September), 25-31.

Rozporządzenie Ministra Spraw Wewnętrznych i Administracji z dnia 3 listopada 2011 r. w sprawie baz danych dotyczących zobrazowań lotniczych i satelitarnych oraz ortofotomapy i numerycznego modelu terenu. Dz.U. $2011 \mathrm{Nr}$ 263, poz. 1571.

Rozporządzenie Rady Ministrów z dnia 15 października 2012 r. w sprawie państwowego systemu odniesień przestrzennych. Dz.U. 2012, poz. 1247.

Ruzgienė B., Berteška T., Gečyte S., Jakubauskienė E., Aksamitauskas V.Č., 2015: The surface modelling based on UAV Photogrammetry and qualitative estimation. Measurement, 73, 619-627, <http://doi.org/10.1016/j.measurement.2015.04.018>.

Siebert S., Teizer J., 2014: Mobile 3D mapping for surveying earthwork projects using an unmanned aerial vehicle (UAV) system. Automation in Construction, 41, 1-14, <https://doi.org/10. 1016/j.autcon.2014.01.004>.

Smaczyński M., Medyńska-Gulij B., 2017: Low aerial imagery - an assessment of georeferencing errors and the potential for use in environmental inventory. Geodesy and Cartograph., Vol. 66, No. 1, 89-104. DOI: 10.1515/geocart-2017-0005.

Stępień G., Metynowska M., Antosik A., Sanecki J., Beczkowski K., Klewski A., Borczyk K., Hałaburda R., Olek K., 2018: Application of UAV for Rapid Mapping Purposes. Top 5 Contributions in Sensor and Biosensor Technology, Avid Science.

Tofani V., Segoni S., Agostini A., Catani F., Casagli N., 2013: Technical note: use of remote sensing for landslide studies in Europe. Nat Hazards Earth Syst Sc., 13, 1-12.

Torres M., Pelta D.A., Verdegay J.L., Torres J.C., 2016: Coverage path planning with unmanned aerial vehicles for $3 D$ terrain reconstruction. Expert Systems with Applications, 55, 441-451.

Toutin T., Chenier R., 2004: GCP requirement for high-resolution satellite mapping. XX ${ }^{\text {th }}$ ISPRS Congress, 12-23, <http://www.cartesia.org/geodoc/isprs2004/comm3/papers/385.pdf>.

Uysal M., Toprak A.S., Polat N., 2015: DEM generation with UAV Photogrammetry and accuracy analysis in Sahitler hill. Measurement: Journ. of the Internat. Measurement Confederation, 73, 539-543, <http://doi.org/10.1016/j.measurement.2015.06.010>. 
Wang J., Garratt M., Lambert A., Wang J.J., Han S., Sinclair D., 2008: Integration of Gps/Ins/ Vision Sensors To Navigate Unmanned Aerial Vehicles, 963-970.

Watts A.C., Ambrosia V.G., Hinkley E.A., 2012: Unmanned aircraft systems in remote sensing and scientific research: Classification and considerations of use. Remote Sensing, 4, 16711692, <https://doi.org/10.3390/rs4061671>.

Westoby M.J., Brasington J., Glasser N.F., Hambrey M.J., Reynolds J.M., 2012: 'Structure-from-Motion' photogramme- try: A low-cost, effective tool for geoscience applications. Geomorph., 179, 300-314. 